\title{
Negotiating creation in imperial times (Rm 8:18-30)
}

\begin{abstract}
Author:
Jeremy Punt ${ }^{1}$

Affiliation:

${ }^{1}$ Faculty of Theology,

University of Stellenbosch,

South Africa

Note:

This article is an edited version of a paper read at 'Creation, Conflict and Cosmos: A Conference on Romans 5-8' at Princeton Theological Seminary, Princeton, NJ, United States, 02-05 May 2012.
\end{abstract}

\section{Correspondence to:}

Jeremy Punt

Email:

jpunt@sun.ac.za

\section{Postal address:}

Private Bag X1, Matieland

7602, Stellenbosch,

South Africa

Dates:

Received: 06 June 2012

Accepted: 03 Oct. 2012

Published: 26 Feb. 2013

How to cite this article:

Punt, J., 2013, 'Negotiating

creation in imperial

times (Rm 8:18-30)'

HTS Teologiese Studies/

Theological Studies 69(1)

Art. \#1276, 8 pages. http://

dx.doi.org/10.4102/hts.

v69i1.1276

\section{Copyright:}

C 2013. The Authors.

Licensee: AOSIS

OpenJournals. This work

is licensed under the

Creative Commons

Attribution License.

Read online:
Appreciation for the literary qualities and structural function of Romans 8:18-30 abounds. Recently, some attention has also been given to ostensible anti-imperial sentiments in the letter that Paul directed to a Jesus-follower community in the heart of the Roman Empire. Tensions and ambiguities inherent in this passage become more pointed when it is read with attention to the interplay between creation, conflict and empire. The focus of this contribution is on how creation is portrayed and negotiated in Romans 8:18-30, given its underlying Jewish setting which ought to be filled out by the imperial-infused environment. Acknowledging an anti-imperial thrust in Romans 8:18-30 but reading from a postcolonial perspective offers the advantage of accounting specifically for ambivalence typical of conflict situations characterised by unequal power relations, all of which are appropriate and vital for the interpretation of this passage.

\section{Situating the argument}

Paul's argument in Romans presented the process of the divine recreation of the cosmos as (to use modern terms) the sequel that has become the prequel to the story of divine liberation: God turning back the clock and remaking, redoing, since his most recent work has been seised and has thus been compromised. In Romans, the recreated cosmos is an understanding and expression framed according to Jewish sentiments, ${ }^{1}$ forcefully expressed in an imperial-infused environment, in a letter directed to a community living in the heart of the Empire. Theologically speaking, the two central elements informing Paul's notions about recreation were eschatological expectation and divine incarnation. These were influenced by apocalyptic and sapiential Judaisms, ${ }^{2}$ which in the process fused two horizons, namely an eschatological future and a restored creation (Ruether 1996:47-61). Rooted in his Jewish traditions, with resounding intertextual echoes and suffering as prelude to redemption, Paul's argument in Romans tilted towards the apocalyptic. Moreover, and also in focus here, Jewish ideas were stretched beyond their original scope in the negotiation of creation in contrapuntal way within the Roman imperial setting - as testified to in Romans 8:18-30.

True to imperial style, the Roman Empire had the keen resolve to assert its dominion over both creatures and creation, claiming for itself the right to rule over the cosmos. ${ }^{3}$ According to the reigning 1st-century Greco-Roman imperialist cosmology, the Romans had already brought about the golden age of peace and prosperity. In a world formatted by such convictions, Paul's understanding of recreation was primarily moulded, however, by Jewish apocalyptic notions. And, his views did not make for a good fit with imperial designs. The dissonance was in no small way due to the formative contexts of apocalyptic thinking, which was formed amongst people who experienced their existence in society as threatened to such an extent that life was experienced as senseless and which gave rise to a new ideological understanding. Marginal groups that were formed as a result were in conflict with society at large, living by the conviction that a fundamental break with the present was required, a break which was linked to new possibilities. ${ }^{4}$ In apocalyptic self-understanding accompanied by high levels of pessimism about the current state of affairs and the present time, the own group is often perceived as suffering unjustly and in any case estranged ${ }^{5}$ from the majority and their symbols of meaning. ${ }^{6}$ This appears to be the pervading sentiment of Paul's letters too, and his anticipated new world was one characterised

1.It is generally believed that Jewish wisdom traditions primarily related God to creation, in distinction from the Exodus traditions that related God to liberation, prophetic traditions that related God to justice and apocalyptic traditions that related God to eschatological renewal (e.g. Sobrino [1978] 2002).

2.The larger debate on whether the plural is applicable to Second-Temple Judaism cannot be addressed here. My point of departure is the absence of a singular, normative and/or orthodox notion of Judaism in the 1st century CE, taking its characteristic pluralism seriously.

3.For recent work on reading New Testament documents in the context of (and even in juxtaposition with) empire, cf. inter alia Crossan and Reed (2004), Elliott (2007), Georgi (1991), Horsley (1997, 2000, 2004) and Jewett (2004).

4.Martin's insistence that 'Paul's apocalyptic revolution is constrained by his physiology' that was 'unalterably hierarchical' can be granted. However, that it further implied that creation will be 'redeemed' rather than 'destroyed or abandoned' claiming Romans 8 as point of reference is putting the case too strongly (Martin 1995:131). All indications are that Paul anticipated a strong, comprehensive point of reference is putting the case too strongly (Martin 1995:131). All indications are that Paul anticipated
and full cosmic upheaval, turning the world on its head (cf. Georgi 1991), the current replaced by the new.

5.The estrangement did not mean, however, that the dominant discourse were not taken up by the in-group and remade, tailored and outfitted for the in-group's own purposes.

6.Sutter Rehman (2004:75-76) cautions against 'a perspectival blindness' when it comes to evaluating apocalyptic sentiments, as the decline of the current world order and new beginnings may carry different connotations and be valued differently by groups in society. 
by God's rule, by judgement over the majority and by justice for the faithful minority, for the disadvantaged. In a powerful argument in Romans 8, Paul's rhetoric engaged themes and assumptions about the created world that were widespread and influential in the Roman Empire.

\section{Roman Empire and (as) cosmic order}

Rome saw fit not only to devise policy to suit its own interests but also reinvented history to serve imperial purposes (Mattingly 2010:75-93). ${ }^{7}$ On the one hand, imperial ideology is of course in a vital way an exercise in history-making. ${ }^{8}$ The Empire underwrote its conquest of geopolitical space in the form of imposing a singular and matching order upon various peoples around the world. In other words, imperial discourse was heavily invested in making memory given the relationship between $r e$-membering memory and re-writing history. ${ }^{9}$ A shared historical narrative was created through inscriptions and statues in particular to reproduce the emperor's power, to give it legitimacy: 'power was written into the physical fabric of provincial towns' (Revell 2009:107). On the other hand, imperial ideology was also about the recreation of the world and the world-order writ large (cf. Kahl 2010; Lopez 2008). In its concern about the interests of the Empire, imperial ideology's cosmological assertions about the current world order were supplemented by claims about the world remade.

Many examples of the ideological investment and claims about empire remaking the world can be cited. ${ }^{10}$ An early instance, Virgil's description of Aeneas' shield, ${ }^{11}$ 'the most symbolic object mentioned in the whole of the Aeneid'

7.Christian empire or Christianity in the end, and notwithstanding its perpetuation of slavery and savage judicial penalties (and still unequal, although no longe restricted to the non-elite), by breaking the elite's monopoly contributed to the ideological consensus that deleted the non-elite from contemporary cultura consciousness (Perkins 2009:172-181). It remains a question whether the non-elite was subsequently allowed agency and voice in memory and historical narrative?

8.Polybius (Histories 1.7-9) also suggests that, in Rome, the history of the world united into a universal history. Cf., for example, Quint (1989:10)

9.A particularly good example of imperial re-membering of history is how the republic of the past was taken up and used in imperial (=principate) memory (cf. e.g. Gowing 2005).

10.For an extended argument that Paul's use of 'the appointed son of God in power' in Romans 1:4 sets the scene for understanding Romans as Paul's response to the Aeneid, that Paul countervailed Virgil's philosophical framework and majo themes and even invalidated Virgil's purpose in writing an epic, cf. Wallace (2008). Wallace is of the opinion that the Romans-letter/Aeneid comparison amounts to more than coincidental analogies or Paul's reaction to some general Roman values. 'Paul's gospel follows a similar philosophical framework that the Aeneid employs ... It is likely that Paul incorporates a religious-philosophical framework centring around a faithful Christ-king who bring earthly disorder into conformity with the divine blueprint, with ríris as the bond of the Christion conforistian community' (Wallace 2008.195). Cf. Jewett (2004.27) on the link between Virgil's Aeneid and Caesar Augustus. fur Aur demonstified in Augustus' claim in his Res Gestae to have subjected the whole world to the dominion of the Roman People.

11.With Venus' concern about Aeneas' upcoming war, she persuades her husband Vulcan, the god of fire and forging, to make Aeneas new weapons and armour fo added advantage. After Vulcan and his workers (Cyclopes inside the great volcano Etna) had completed their assignment, Venus (also known as Cytherea, after Cythera, the island where she was born and her shrine was located) handed the weaponry over to Aeneas at the end of the following day: helmet, corselet, sword, spear, and shield, exquisitely crafted and stronger than metal forged by humans (Aeneid 8.370-453; 585-625).
(Vella 2004:2), is particularly instructive. ${ }^{12}$ Virgil's description of the shield of Aeneas (Aeneid 8.626-731) is written as anticipation of the inception and splendour of the Roman Empire, prefigured also in the battle of Actium and its aftermath. ${ }^{13}$ As for the shield's version of the battle of Actium, the ideological concerns of the Roman Empire found their expression primarily in the contrast between the imperial forces and its opponents. The Western imperial forces led by Octavian - already named Augustus by Virgil is characterised by unity, control and order, and, importantly, exhibits cosmic order in their reliance on and support by Apollo, the fastener of Delos. ${ }^{14}$ In sharp contrast, Marc Antony in his alliance with Cleopatra personified the East, who was ascribed notions such as disparity, loss of control and chaos. ${ }^{15}$ The Eastern forces were disorderly, incoherent, savage, barbarian hordes with their wealth and power no match for the one imperial unity, moulded out of conquered nations into an unending Empire (Aeneid 1.279; cf. Quint 1989:3-6). Significantly, such imperial re-membering or recasting of history was not limited to distinctions between friend and foe; it also remodelled cosmos as imperial ideology sought to align empire and world.

Virgil's description of the battle of Actium extends its imperial gaze and ideological impact beyond a fight for supremacy within the Empire or for the control of its vast territories, power and wealth. He portrayed the struggle between the two armies as also having cosmic implications. The very integrity of the natural creation is at stake as the mythological analogies ${ }^{16}$ between the uprooted Cyclades islands (8.691) and mountains attacking each other (8.692) and the battleships of Octavian and Antony seem to suggest. The notion that Delos is loosened from its moorings and mountains are becoming the weapons of giants amounts to nothing less than 'a decreation of the cosmic order' (Quint 1989:7). ${ }^{17}$ It was the cosmological dimensions of the

12.Virgil's Aeneid is most often dated around 19 BCE. 'The Aeneid is ... a spiritual book that Vergil composes: the triumph of good over evil, the reconciliation of the gods, and faith in divine promises' (Vella 2004:12). For literature on the Shield of Aeneas, cf. Vella (2004:6, n. 23). Vella argues that the shield is one element of ecphrasis in the Aeneid, 'a sub-genre whereby an author brings the narrative of events to in the Aeneid, a sub-genre whereby an author brings the narrative of events to halt in order to offer pause for a detailed act of description' (Vella 2004:6-7) Often longer than a mere word, with literary embellishments, such to
symbolically and are representative of the society an author portrays.

13.Faber (2000:49-57) is probably correct in arguing that Virgil's account of Aeneas' shield was based on the Achilles' shield in Iliad 18 or took a cue from the Shield of Heracles by Pseudo-Hesiod (617-625)

14.In Aeneid 8, Octavian's army is presented as a national unified force (agens Italos, 678; patribus populoque, 679), fully under control (stans celsa in puppi, 680; parte alia uentis et dis Agrippa secundis, 682; Augustus at the rudder) and all in order (incedunt uictae longo ordine gentes, 722).

15.The Eastern forces are characterised as many (uariisque armis, 685; Eastern overpopulation and fertility), without control (ipsa uidebatur uentis regina uocatis/ uela dare, 706-707; Cleopatra at mercy of the winds) and in flux, without order (Nile, 711-713; suicide, death wish) (Vergil, Aeneid 8).

16.The wandering Delos was the central island of the Cyclades and became the birthplace of Apollo when, as a reward, the god chained it into place and made it his shrine (Aeneid 3.73-76; Propertius' poem on Actium, 4.6, also mentions Delos anchored under Apollo's protection).

17.Many imperial buildings also emphasised the benefit of Roman control over the cosmos exemplified by the portrayal of earthly fertility and abundance on some of the (Eastern Wall) panels on the Ara Pacis which was consecrated in 9 BCE by the Senate. Also depicted on the altar is the 'image of the pious Trojan hero Aeneas who [are] making sacrifices on the shore of Latium paired with a similarly pious Augustus offering sacrifices for the Roman people (Elliott 2007:183). For the emphasis on piety, amidst public grandeur and civic works programme in Augustus' political agenda, cf. White (1999:110-135)' (Punt 2012:p. 4 of 11). 
battlefield that illustrated the broader reach of these events of which the religious dimension included the involvement of the gods.

Large-scale, cosmological events were not restricted to military events or political moves in ancient times where religious connotations saturated the understanding and portrayal of such events. The overt and particular religious aspect of the Western force being supported by the acknowledged gods such as Neptune, Venus and Minerva (8.699), and Apollo in particular (8.704-705), is offset by the 'monstrous gods' (omnigenumque deum monstra et latrator Anubis, 8.698) of the East, presented as the gods of war and disorder. Through the skilful framing of the battling groups with their divine consorts, the superiority of the West in rationality, temperament and even their gods were emphasised. It is only when the Furies of War, Discord and Strife have spread confusion and destruction that Apollo intervened. As the God of Western rationality, the disorder and violence of the Eastern soldiers and Cleopatra were not ascribed to Apollo's appearance, but in their panic (6.704-708), they became the embodiment of chaos and violence. Notwithstanding their equal involvement in the hostilities and its violence, especially here in the context of a civil war, the violence of war becomes the norm of the East in contrast to the West whose soldiers are marked not by war but by order and appeasement (Quint 1989:8).

Imperial ideology dictated a vision of the world subservient to the Empire, redescribing and in fact re-membering history and thereby formatting the cosmos for the Empire's sake. Paul's claims about the world and its recreation are reminiscent of imperial ideology. The logic of Paul's argument in Romans 1-8 culminated in 8:18-30 in his vision of a corrupted world on the verge of a divine made-over, a recreation. In Paul's understanding, God was not only the author of recreation but also closely associated with the plight of people. Amidst much discussion about the meaning and implications of the Spirit's intercession with 'wordless

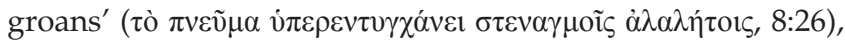
the sentence underlines the connections between the divine, suffering and recreation. Paul's argument relies on the scriptural notion that God suffers with his people in unjust suffering (Ex 2:23-25;3:7-8), that, in fact, God suffers because of his people's unrighteousness (Jr 3:19-20) even when God is the author of the suffering (Hs 11:8). The point here is that the groaning of the Spirit identifies with the groaning of the creation. ${ }^{18}$

The cosmological impact of the imperial remaking of the world, however, went further. For 1st-century people, the connection between the inherent, innate order of creation and codes of morality was given and therefore important. As Sutter Rehman (2004) puts it:

Paul's speaking of sin refers to the daily reality of life in the Roman Empire, the imperium romanum. His idea of $\sin$ is

18.There is some irony in the fact that God, through the Spirit, is suffering under his own curse which He pronounced on Adam, namely the pain concomitant with childbirth. Whether one should understand the flood narrative and groaning of people and earth as intertext for Romans 8:26 (cf. Dunn 1988), is another question (cf. Dunn 1999:82-91). expressed in categories of domination and not those of guilt or action. (p. 78)

When Paul re-invoked the notion of evil, it was not simply about wrong but about evil, that is, about the distortion of what life and the world is meant to be. ${ }^{19}$ In short, imperial cosmology presents an interesting template for framing Paul's cosmological views. In this, my focus is on the ideological dimensions and dominations of imperial discourse rather than on the material or ecological realities of imperial destruction.

\section{Romans 8:18-30 as imperial- inflected text}

Notwithstanding the apparent support listed and required for imperial authority in the very explicit Romans 13:1-10, ${ }^{20}$ traces that suggest both criticism (whether implicit or direct) of imperial ideology as well as an attempt to construct another vision of the world can be found in Romans. However, life in a geo-political context of uneven power relations was not necessarily and certainly not only about subversive resistance. Postcolonial work in particular shows that the embracing of symbols of power is a strategy of control, not simplistically a sign of submission. A postcolonial optic is sceptic about simple oppositions and speaks of 'negotiation' in terms of the exercise of power by both the 'dominant' and the 'dominated,' as it recognises the complexity and reciprocity of the interaction. In exploring what can be called the subservient submissiveness found in the Pauline letters, one has to be careful not to dumb down Pauline sentiments to the political in a narrow sense. The cultic element in the Pauline notion of participation in Christ, ${ }^{21}$ of possessing and being possessed by a saviour, can be seen also as a claim to or an exercise of power. ${ }^{22}$ Participation in Christ made present what was otherwise distant and functioned simultaneously as the supreme act of identity declaration.

Formulating his argument in Romans 8:18-30 within the very context of imperial cosmic claims, Paul addressed a community confronted by imperial ideology that was inscribed in daily life in various ways. In his letter, Paul approached a community largely unknown to him, ${ }^{23}$ living

19.Not untypical of a Jewish setting with Jesus followers, the cause of evil was attributed to bad faith toward already existing good faith. Theologically speaking, sin and death were conquered in the cross of Jesus, but before they will be eradicated, human beings' faith in God must first be restored by the proclamation of the gospel (Westerholm 1997:94-100).

20.The interpretation of Romans 13 has seen much activity of late. Elliott's work (1994, 2007,2008 ) provides a good overview of positions and also explains his insistence that Romans 13 is not to be read as a call for blind submission to empire's demands that Romans 13 is not to be read as a call for blind submissior

21.Cf. for example discussions in Bassler (2007), Campbell (2005), Howell (1994) and Meech (2006). Further investigation of resonances between possessive language used in the cultic as well as social contexts (such being possessed by a lord, with patronage as larger framework) may render interesting results.

22.First-century politics was at any rate about more than a position for or against ruling authorities and accompanying actions. Politics was embedded in society which saw people participating as agents (however circumscribed such roles were) as a result of continuous constructions and construals of relations of power. Thus, as a result of continuous constructions and construals of relations of power. Thus, Bourdieu's concept of habitus, for instance, explains how social groups undertake it (Bourdieu 1990:52-55).

23. At the point of writing, the impression is that Paul had never visited the Roman Jesus-follower communities, writing to people unknown to him and people who did not know him. Chapter 16 with its many biographical references probably did not know him. Chapter 16 with its many biographical references probably
serves as Paul's inverted testimonial, as referrals to the author-apostle unknown or perhaps otherwise known to the community. 
in the heart of the Empire in Rome, the locus of many disturbances, some of which had disastrous consequences such as the (at this stage, recent) expulsion of Jews by Emperor Claudius in 49 CE. Paul's letter appears to have been an effort to secure support for his mission as he apparently needed help with its intended expansion to the West and therefore had to show himself as friend and not foe of Jesus or his followers (cf. Longenecker 2011:272-274). Our focus is on Romans 8:18-30, the position of which in the letter is at once indicative of its strategic importance and also illustrative of the letter's grain and texture. The passage plays a key, connecting role in the argument of the letter in three ways. Firstly, as the climax of the discussion in chapter 8 and of 8:17 in particular, it builds on notions of freedom from slavery $(8: 2,21)$, resurrection $(8: 11,23)$, sonship and adoption $(8: 14-17,19,21,23)$, the role of the Spirit $(8: 6,11,15-16,23,26-27)$ and suffering $(8: 17,18-23,26)$ and glory $(8: 18,30)$. Secondly, it is also the culmination of Romans $6-8$ and even of Romans $1: 18-8: 30$ as it provides an argument on the reversal of human failure and restoration of people, the 'cosmic outworking of salvation in strong Adam terms' (Dunn 1988). ${ }^{24}$ Thirdly, Romans 8:18-30 sets the tone for Romans 9-11 with its argument on God's faithfulness explained according to traditional Jewish motifs. ${ }^{25}$ The blessings typically seen as belonging to Israel have now become the inheritance of all (cf. Dunn 1988).

A central element in Romans 8:18-30 involves the portrayal of the cosmos, its current state as well as its anticipated future. A portrait is presented of an overpowered, subjected creation that groans for redemption and whose remaking is emphasised by Paul - a portrait that does not escape the ambiguity of Paul and his argument's position vis-à-vis the Empire. Nevertheless, in all three of these respects (considered separately below), echoes of Paul's Jewish traditions shine through in portrayals which contrast significantly with the cosmological image presented by imperial ideology.

\section{Overpowered, subjected creation}

As a Jew, Paul shared the Jewish notion that creation is subjected against its own will $(\operatorname{Rm} 8: 20)^{26}$ and described its position as characterised by destruction or corruption ( $\varphi \theta 0 \rho \alpha ́, 8: 21)$ and futility ( $\mu \alpha \tau \alpha$ ó $\tau \eta \varsigma, 8: 20)$. That creation

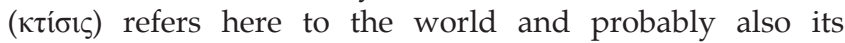
inhabitants is generally accepted. ${ }^{27}$ Although the language

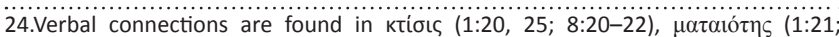

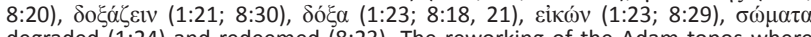
degraded (1:24) and redeemed (8:23). The reworking of the Adam topos where the restoration of cosmic order is dependent on human restoration $(8: 19-23)$ lines up with Adam-Christology of Romans 5:12-21.

25.Such themes include present suffering and future vindication ( $R m 8: 18)$, final time analogous to primal time (8:21), the Adam theme, divine intercession ( $8: 26)$, 'he who searches the heart' $(8: 27)$. Language typical of Jewish tradition includes birth pangs $(8: 22)$, first fruits $(8: 23)$, hope $(8: 24-25)$, purpose $(8: 28)$ and the group of pangs $(8: 22)$, first fruits $(8: 23)$, hope $(8: 24-25)$, purpose $(8: 28)$ and the group of
terms invoked for Israel: saints, those who love God, the called, firstborn $(8: 27-30)$.

26.There is no gnostic view here of the world as innately frustrating and evil: The

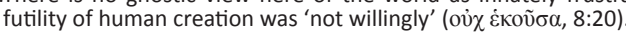

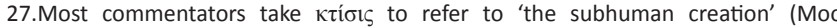
1996:514), 'the nonhuman world' (Fitzmyer 1993:506) whilst some interpret it as 'creature' in the sense of human body rather than 'creation' (e.g. Michaels 1999:93). A full range of options includes all of creation with humans and angels, humankind, unbelieving humankind, believers, only angels, sub-human nature and angels, sub-human nature and humankind, sub-human nature only, Gentile world excluding Jews and the body as either humans generally or believers in particula (Cranfield [1975] 1982:411; Michaels 1999:93). Given the contrasts in Roman 8:18-30, the broadest understanding of $\kappa \tau i \sigma 15$ appears to be most feasible Cranfield [1975] 1982:141-142). Elsewhere $\kappa \tau i ́ \sigma 1 c$ refers to created things (e.g. Rm 1:25; 8:39). reminds of the 'thorns and thistles' bequeathed to the earth in Genesis 3:17-19, understanding vं $\pi \varepsilon \tau$ ó $\gamma \eta$ as divine passive (see Jewett 2004:36) is probably too strong. Paul's damning analysis of the state of the cosmos contrasts with the popular Roman myth that the emperor would have already restored the world to a paradisiacal state. The emptiness evoked by $\mu \alpha \tau \alpha$ ió $\eta$ ऽ depicts a situation reminiscent of Ecclesiastes 1:2, broader devastation than the resultant corruption alluded to in Romans 8:21. The Hebrew Bible told the story of how idolatrous desires for unlimited dominion over the garden destroyed the original purpose of creation which was to express goodness (Gn 1:31) and reflect divine glory (Ps 19:1-4). In the contemporary world, Roman action was destroying the world through imperial ambitions, military conflicts and economic exploitation which resulted in ruined cities, depleted fields, deforested mountains and polluted streams. ${ }^{28}$

Paul's vision was not limited to the current sufferings

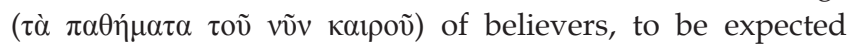
by followers of Jesus (cf. 8:18), as he contrasted these

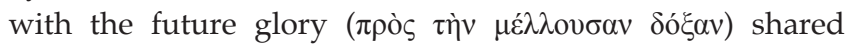
in eschatological solidarity with Jesus. ${ }^{29}$ In fact, with the apocalyptic disclosure of God at hand, believers become

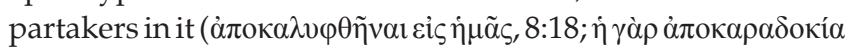

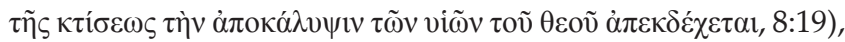
in contrast to the imperial claim that Caesar and only Caesar is associated with glory. The seldom-used $\alpha$ лок $\alpha \rho \delta$ бокí (also in Phlp 1:20) refers to 'confident expectation', that the creation awaits the emergence and empowerment of those who will

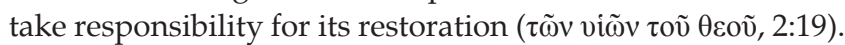
Not only do these converts take the place of Caesar in imperial propaganda, but rather than using weapons against their enemies, their conquest is by persuasion. The matter at hand concerns the rightful dominion over the earth, rather than a modern-day concern with the almost magical transformation of nature. Paul described a cosmos in dire straits!

\section{Creation's groaning for redemption}

Parallel to Jewish tradition (cf. 1 Enoch 7:6; Ps 65:13-14; Is 24:4, 7; Jr 4:28; 12:4) and Roman imperial use, Paul personified the entire $\operatorname{cosmos}(\pi \tilde{\alpha} \sigma \alpha \dot{\eta} \kappa \tau i ́ \sigma \varsigma)$ as a range of animate and inanimate objects on the earth and in the heavens, a holistic, interdependent system with life and development of its own. ${ }^{30}$ However, rather than making claims about nature's joy at deliverance through Augustus, Paul in contrast heard only

28.According to [Paul], the whole of creation is subjected to the pressure of Roman economic and military laws as well as to the pressure to conform and keep quiet. Such pressure causes all human beings to groan' (Sutter Rehman 2004:78). It is therefore not sufficient to see the agency of the domination and exploitation as limited to celestial powers or as the inability of the natural world to fulfil its mandate to glorify God due to the disobedient failure of people to play their primary rational part (cf. Cranfield [1975] 1982:413-414).

29.Glory here probably refers not so much to the Greco-Roman version amounting to opinion or reputation, ascribed by public opinion. It is more likely the Hebrew sense (kabod) of innate weightiness, honour, beauty, fiery presence, splendour and power that is at play here. The glory of God in the Hebrew Bible concerns the fiery phenomenon of radiance and brilliance (cf. Ps $8: 1,5)$. The connection is also made phenomenon of radiance and brilliance (cf. Ps $8: 1,5)$. The connection is also made
between glory and restoration as is found in prophetic and post-exilic traditions (e.g. Is 24:23; cf. Dunn 1988). God has subjected creation to decay and futility in (e.g. Is 24:23; cf. Dunn 1988). God has subjected creation to decay and
order to achieve the ultimate goal of divine glory (Stowers 1994:283).

30. However, unlike the Romans and other ancients who set great stock by an eternal Mother Earth, Paul's emphasis was on the purposeful creation of the natural order by God at a particular moment in time ( $\mathrm{Rm} 8: 19)$. 


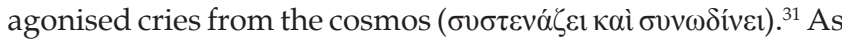
emphasised by the preposition $\sigma v v$ ('together'; and borne out by $8: 23$ ), it was a shared experience for believers and creation alike. ${ }^{32}$ They shared both the groaning and the longing for new life. Paul assumed some acquaintance amongst the recipients of his letter with the idea of the corruption of nature (oi $\delta \alpha \mu \varepsilon v$ $\gamma \grave{\alpha} \rho)$, a notion he may have sourced from Second-Temple notions of mourning and suffering caused by the burden of human exploitation (cf. Is 24:4-7). Groaning that lasts 'until

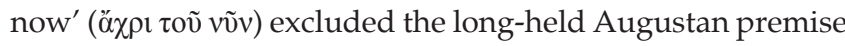
of a golden age, as inaugurated by the Saecular Games of 17 $\mathrm{BCE}$, the purpose of which was to celebrate the birth of a new age in which specifically the fertility of Mother Earth played a prominent role. ${ }^{33}$ At the time of Paul's writing of Romans, cosmological groaning complicated the notion that Nero ushered in a golden age of undisturbed peace. At the same time, Paul's terminology invoked gender associations which were not unfamiliar in imperial ideology.

The imperial portrayal of Octavian in Virgil's description of the shield of Aeneas (Aeneid 8.675-728) exemplified the use of gendered notions. Unity, control and order were expressed in masculine terms (patriumque...sidus, 681; and the role of Agrippa, 682) whilst, conversely, the enemy from the East took on a female identity (Aegyptia coniunx, 688). Relating the otherness of the East to the otherness of the other sex, Cleopatra ended up receiving more attention on Aeneas's shield than Antony. This rendition highlighted the belief that the forces inherent in the East, in the cosmos and in the human psyche were feminine (Quint 1989:4, 8). ${ }^{34}$ The association of the East with fertility is made present by the Nile as the East is manifested in this and other rivers such as the Euphrates, Rhine and the Araxes at the Empire's frontier, rivers being analogous to fertility (1.726-728). Eastern fertility is identified with 'the cyclical fluid fertility of woman', both of which are identified with nature's creative potential (Quint 1989:10). As much as the Empire conquers space, its victory over the river expands the imperial cosmic reach, and with the river as Heraclitean symbol of flux, it signified the Empire's victory even over time (Quint 1989:10). Paul's metaphorical descriptions of creation and recreation were not as elaborate but included the biological metaphors of birth and children. Developing a notion found in Romans 8:18 already, believers were included in the suffering

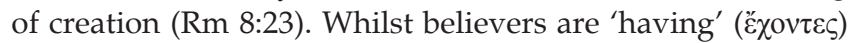
the first-fruits of Holy Spirit, ${ }^{35}$ they are nevertheless 'awaiting

31.As in Romans $8: 23$, in 2 Corinthians $5: 2,4$, Paul and the followers are the subject of $\sigma \tau \varepsilon v \alpha$ ' $\zeta \varepsilon I v$ 'groan'. In the New Testament, the cosmos is the subject of groaning only

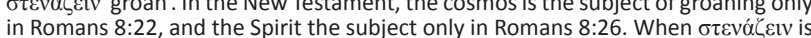

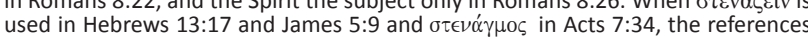

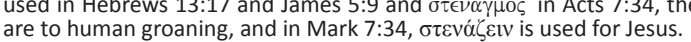

32.'Paul does not position Christians here and creation there, the redeemed here and those who suffer there, a gender-neutral or male-oriented community here and a nature perceived as feminine there' (Sutter Rehman 2004:77).

33.The poem Carmen Saeculare (secular hymn or song of the ages) by Horace was officially commissioned for the celebrations. The renewal of the earth was a prominent feature in the poem: 'Fertile in fruit and flocks, the earth, May she endow Ceres with crown of grain; May both healthful waters nourish the harvests, And Jove's breezes' (Horace, Carmen Saeculare 29-32).

34.'The danger for the West is to repeat the fate of Antony, to become Easternized and womanish' (Quint 1989:9).

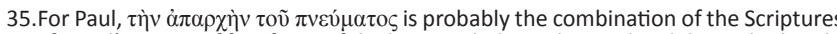
of Israel's notion of first fruits of the harvest dedicated to God and the early church' concept of the Spirit as identifying mark of believers.

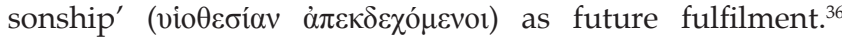
Believers participate in the suffering of the world, yet they treasure the hope that the full and undistorted dominion of God's children will one day manifest itself in context of the restored creation. It is telling, though, that Paul put the

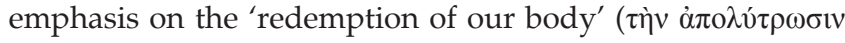

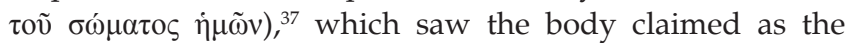
basis for communicating and interacting with the world. His thought holds no redemption from the body as some form of individual sense of detachment. Rather, he proposes redemption of the body as part of the socially transformed creation, no longer subject to 'corruption' (cf. Jewett 2004:45). ${ }^{38}$

It is limiting to interpret the birthing metaphor of Romans 8:22-23 as reference only to pain and suffering with the consequent implication of quiet endurance and patience. As has happened in much mainstream interpretation, suffering then becomes a condition of humanity, and the emphasis shifts to the metaphysical benefits of salvation. ${ }^{39}$ When birthing is about more than suffering, pain and producing children, the emphasis shifts to hard work and bodily exertion for the sake of a new life in the face of resistance ${ }^{40}-$ and, as a consequence, the cultural denigration of bodilyness or corporeality is challenged (Sutter Rehman 2004:74-84). ${ }^{41}$ The language of pain and suffering in Romans 8 comes close to lament, especially when used together with credo recital and songs of thanksgiving. As a form of subversive speech which begins in pain and ends in praise, lament always begins in a context of suffering and always functions as an appeal (Keesmaat 1999:97-135). Groaning is not tantamount to resigned patience but participatory resistance aimed at the future realisation of new reality. It means that creation is to be re-created, to be made over!

\section{Remaking creation}

In Jewish tradition, new-creation language was invoked for individual converts (cf. Genesis Rabbah 39.4), for the

36.In Romans 8:15, the Spirit appears to confirm it as present reality, though. This claim, however, is a repetition of that which is found in 8:19 also, awaiting the claim, however, is a repetition
revelation of the sons of God.

37.The term $\dot{\alpha} \pi \circ \lambda v^{\prime} \rho \omega \sigma \iota \varsigma$ derives from the military, used for the redemption of captives or prisoners of war by victory or paying ransom. The community is designated as people of status and means.

38.It was during the Maccabean period and in response to their plight and suffering that apocalyptic thinking became important in Second-Temple Judaism. Jewish apocalyptic thinking incorporated bodily resurrection, serving the further purpose of distinguishing between the oppressed and the oppressors (Segal 2004:269).

39.Cf. for example Jewett (2004:41-42) on Romans 8:22-23 as human suffering in the

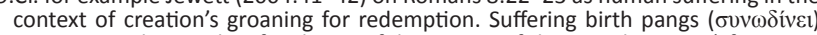
is a scriptural metaphor for the painful prospect of divine judgement (cf. Is 13:8; 21:3; 26:17-18 - also 1 Th 5:3). Is the assertion that Paul relied on participationist theology here, that it is an honour for people to suffer the same as what Jesus had suffered not an exaggeration of the text? It is probably better to acknowledge had suffered not an exaggeration of the text? It is probably better to acknowledge
that Jesus' suffering initiated a troubled period for the faithful which serves as transition to the divine redemption of the world (cf. Stowers 1994:283).

40. Not to sigh quietly and practice patience is precisely the point here; the issue is to cry aloud, to protest, to demand abundant life and justice', and ' $[b]$ irthing is not an impotent whimpering of poor female bodies, nor is it passive suffering. Above all, it is action' (Sutter Rehman 2004:75, 84, emphases in original). Sutter Rehman (2004:82) criticises Gaventa (2007) for focusing on the pain and suffering of birthing and supports her argument with Isaiah 13:8 and Jeremiah 4:32 (where birth is connected to punishment and death).

41.New creation implies structural change: 'Whether it is correct to speak of Paul's identification with labouring motherhood as a 'metaphor squared', the image of Paul having birth pains symbolizes his labor for a new creation based on the desire for a different configuration of relationships between Jews and others, echoing for a different configuration of relationships between Jews and others, echoing
his scriptural context (especially the prophetic tradition) and challenging his 'exilic' his scriptural context (especially the prophetic
situation under Roman rule' (Lopez 2008:91). 
community of faith (e.g. Is 65:17-19) and for the cosmos (e.g. Is 56-66). New-creation language in Paul's thinking had twin characteristics. On the one hand, reconciliation saw believers reconciled to God and the imperative to work for the reconciliation of the world to God through Christ. On the other hand, new creation was about the rejection of worldly standards, as for example in ethnic divisions between Jews and Gentiles or in individual rivalry (Levison 1993:189-190). Paul's claim that creation itself will be set free from Adamic distortion (8:21) built upon a significant theme in Jewish prophecy and apocalyptic (cf. Is 11:4-5; Jubilees 1:29; 1 Enoch 24-25; 91:16-17; 4 Ezra 13:26; Sib Or 3:744-745; 750-751). Echoing a matrix of ideas rather than specific texts from the Scriptures of Israel, Exodus, Leviticus and Deuteronomy in particular, Paul connected the disruption and death of natural ecological systems with human corruption ( $\varphi \theta$ opó) flowing from the human predicament described as enslavement

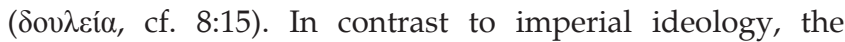
overcoming of ecological disorder is depicted as a divine

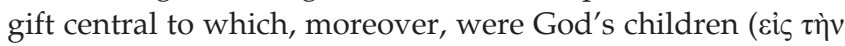

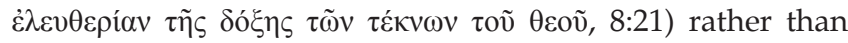
the emperor, priest or empire (Jewett 2004:39). The restored creation will serve the purpose of liberating the children of God. ${ }^{42}$

In Romans 8:24, the argument is not about a Greek philosophical notion of the invisible world perceptible only at rational level but rather about a Jewish apocalyptic notion. According to imperial ideology, 'the length and breath [sic] of the Roman Empire culminated in the rule of Augustus' as Aeneid 8.724-728 makes clear (cf. Vella 2004:10). Paul, however, portrayed salvation not through hope but in terms of hope. ${ }^{43}$ Used three times in short succession, $\dot{\alpha} \pi \varepsilon \kappa \delta \varepsilon \chi \varepsilon \dot{\varepsilon} \sigma \theta \alpha 1$ $(8: 19,23,25)$ marks the character of the in-between time as primarily one of eager waiting. This is a period not of resigned or stoical suffering, and neither is it one of mere anguished groaning or careless enthusiasm. Rather, it is a period of patience with a vibrant quality ( $\delta \mathrm{l}^{\prime} \dot{v} \pi \mathrm{o} \mu \mathrm{ov} \tilde{\Upsilon} \varsigma \dot{\alpha} \pi \varepsilon \kappa \delta \varepsilon \chi 0 ́ \mu \varepsilon \theta \alpha$, $8: 25)$. By associating the charismatic Spirit with human

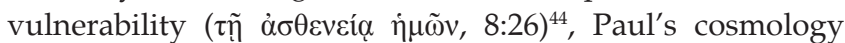
excluded the notion of human beings transformed into deity as was found in the civic cult's apotheosis of emperors (cf. Jewett 2004:44).

Central to Paul's argument was that God had ensured the

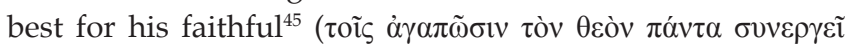

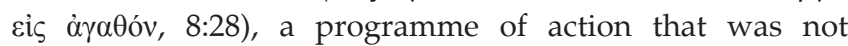

42.Again a scriptural echo sounds in the background, that the deliverance of Israel is for the sake of the whole of creation (Fretheim 2005)

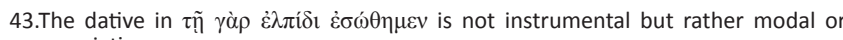
associative.

44.Weakness probably refers to the human condition in this age, to creatureliness, as creature and not creator, with all that that implies for human dependency on divine assistance. Weakness is more than exposure to 'external temptations' or the "inability in prayer as such, but the totality of the human condition (the corruptibility of the body, the subvertedness of the flesh) which the believer is still part of and which comes to expression' in the inability to pray (Dunn 1988). Keesmaat (1999) sees an allusion to the sufferings of the eschatological struggle Keesmaat (1999) sees an allusion to the sufferings of the eschatological struggle 8:35-38 on the list of apocalyptic trials).

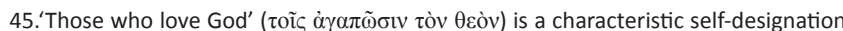
of Jewish piety. It takes up only the first part of the regular formulation, thereby
evoking Christianity's Jewish inheritance whilst at the same time separating it from evoking Christianity's Jewish inheritance whilst at the same time separating it from its more distinctively Jewish devotion to the Torah. dependant on whims but was tied to God's larger purpose

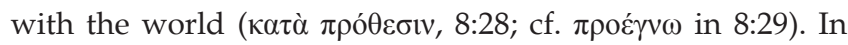
this, he shared the characteristic Jewish thought ${ }^{46}$ of God's (pretemporal) purpose moving history and through history moving it to its intended end (cf. Ps 33:11; Pr 19:21; Is 5:19; 19:17; 46:10; Jr 49:20; 50:45). The human being as likeness of

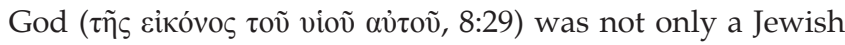
notion, but given the position of the Adam theme in the letter (Rm 1:22-24; 3:23; 5:12-19; 7:7-13; 8:20), the Jewish tradition is probably influential here too. The resurrected Christ is described as the pattern of the new humanity of the last age, the firstborn (of the dead) of a new race of eschatological

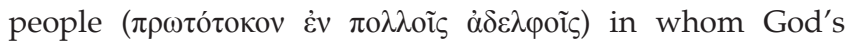
design from the beginning of creation is at last fulfilled. ${ }^{47}$

In Romans 8:29-30, Paul's argument dispelled any final doubts about the agent of recreation as he deliberately set the timeline of cosmic and human history between two markers, pre-temporal purpose and final glorification as the completion of that purpose. This is not without some irony. Despite the fact that humans were so reluctant to bestow the glory upon God that He rightfully deserved (Rm 1-2), God now nevertheless bestows glory upon humans.

\section{Romans 8:18-30, empire and ambiguity}

Given such comparisons, the tension between imperial cosmology and Paul's portrayal of it is evident. To recognise the influence of his Jewish traditions is important, but to resolve the tension between imperial and Pauline cosmologies as an unfortunate clash of traditions is tantamount to a disregard for both the ubiquity of empire in the 1stcentury and the address of the Romans letter. ${ }^{48}$ However, the intentional fallacy is only one of many dangers in seeing a more deliberate explicit or subtle implicit (hidden transcripts) attempt by Paul to push back empire, to subvert imperial claims, to challenge imperial ideology. Be that as it may, his argument in Romans 8:18-30 involved Paul in the struggle for rightful dominion over both its inhabitants and the very earth itself.

Paul would not have been the only 1st-century author to voice, even if only in an implicit way, discontent towards the Empire. Regardless of the overbearing ideological power of the Roman Empire, criticism against it was not absent, either from within or from without, and not only about isolated, pragmatic concerns. For example, some internal criticism of the imperial ideological onslaught of the Empire 46.For $\pi$ pó $\theta \varepsilon \sigma t v$, cf. Romans 9:11; Ephesians $1: 11$; $3: 11$; 2 Timothy 1:9; Philo, Mos.
2.61.

47.The closest parallel indeed is Hebrew 2:6-10.

48.Also, whilst another contemporary Jew like Philo described the suffering of 'men, women, cities, nation, countries, regions of the earth ... the whole inhabited world'

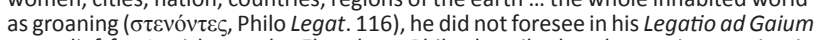
any relief for Jewish people. Elsewhere Philo described such cosmic groaning in any relief for Jewish people. Elsewhere Philo described such cosmic groaning in
the face of Roman oppression as 'most grievous and thickly pressing pain' (Philo, the face of Roman oppression as 'most grievous and thickly pressing pain' (Philo,
Leg.All. 211; Yonge 1993:74). Josephus indirectly speaks of the people's suffering during the Jewish-Roman War of 66-70 CE as groaning when he compares their during the Jewish-Roman War of $66-70 \mathrm{CE}$ as groaning when he compares their
suffering to Jewish groaning under Assyrian rule (Josephus War, 5.384), with no possibility of relief. Cf. Sutter Rehman (2004:78-80). 
can be heard in Lucan's Civil War. ${ }^{49}$ Lucan's depiction of Julius Caesar's defeat of Pompey at Pharsalia as forerunner of Octavian's victory at Actium plays on the notion of the victory of superior, disciplined Western forces over the mixed bag of disparate groups constituting the Eastern army whose unreliability outweighed their numerical superiority (Civil War 7.360-368; 7.269-274, 525-544). Whilst Lucan's analogy attempts to explain the demise of Pompey and his republicans, it also portrays Actium as being less about a celebrated triumph of the Empire over foreign adversaries than about the continuation of Rome's civil wars and the ultimate destruction of her liberty. ${ }^{50}$ Such subtle criticism of imperial ideology should not go unnoticed.

When Paul took up cosmological notions reminiscent of the Empire and when he construed a worldview opposite to imperial ideology, did it constitute or imply a challenge to Roman power? As his argument in Romans 8:18-30 may suggest, it can be read as a contrast and even a challenge to it. However, more is at hand as Paul's vision for the cosmos differed from imperial versions in agency more than in nature - it remained a question of dominion, rightful dominion, but dominion nevertheless. The contrast between imperial discourse and Pauline thinking should not overrun the ambiguity typical of uneven power situations. Depicting the covenant with God as creator in polar opposition to the ideology of empire, the religion of creation versus the religion of empire (e.g. Howard-Brook 2010), may too easily skirt around the ambivalence of the context. Paul's negotiation of power in an imperialist context for example included the claim that the believers waited to be adopted as sons (8:23), which explicitly was 'the redemption of our bodies' and implicitly a claim about the true inheritors of the cosmos - in imperial style. Paul's argument rested heavily on gender-based metaphors, as seen when his focus shifts from creation as a women giving birth to his appeal on 'sonship'. In groaning together, the emphasis is not only on the Spirit's bond with people as the people's involvement with the Spirit also deserves attention. ${ }^{51}$

In other words, does Paul's deft and subtle appropriation of imperialist notions leave him unaffected, or did his cosmology also show signs of the attraction of empire, as is suggested in the linear teleology within which he framed divine recreation? Empire's ideology and its carriers cannot easily be separated from one another, as exemplified in how epic tends to equate power and narrative. A narrative teleology that develops out of an epic linearity stands in close companionship to imperial power: All events lead to an ultimate, imperial-defined end.

49.Lucan was a Roman citizen, probably from the elite, and befriended to Nero as a prominent poet in the imperial court until a fall-out which saw Lucan join Calpurnius Piso's conspiracy to overthrow Nero. Upon discovery, Lucan opted for suicide (65 CE) by which time he had (largely) finished 10 books on which he had worked since approximately $61 \mathrm{CE}$. These books, the historical accuracy of which was probably secondary to the virtues of drama and rhetoric, are collectively known as The Civil War or Pharsalia.

50.'In drawing such a parallel Lucan comes close to equating republican freedom with the cause of the conquered peoples of the East' (Quint 1989:16).

51.The reception history of the text in Reformed churches in particular may have skewed its interpretation to the extent of divorcing Paul's addressees of all responsibility. However, as Sutter Rehman emphasises, " $[t]$ he new earth does not simply fall from the sky; justice does not come about without our cooperation' (Sutter Rehman 2004:81).
Whilst the victorious in an epic project their present power proleptically onto the future as well as trace its legitimating origins to the past, such presentations of power depend on their capacity to maintain themselves over time, and its staying power requires narrative in order to present itself. In a mutual edifying relationship, then, the story of the victorious is identified with narrative meaning itself whilst the power of victory allows the construction of narratives that join beginnings purposefully to ends ${ }^{52}$ (Quint 1989:27).

\section{Conclusion}

Recognising the impact of Paul's Jewish identity and its adversarial implications for an imperial worldview, whether incidentally or intentionally connected, remains important. In viewing the cosmos as a living organism, Paul followed not only in the footsteps of his Jewish tradition but used language prevalent in Roman imperial discourse too - not to mention terminology and concepts remarkably similar in environmental discussions today. On the one hand, Romans 8:18-30 shows the integrated nature of Pauline language - integrated concerning both socio-political and spiritual-theological aspects of and claims to creation and its remaking! ${ }^{53}$ On the other hand, Romans 8 also shows how religion includes strategies for transforming irresistible and indifferent powers into entities with which negotiation and barter are possible. Such powers are transformed not only into manageable portions but are also appropriated, are taken up as 'part of us', in transformations that are not adequately described as merely political resistance given the ambiguity of power and its influence of all involved.

\section{Acknowledgements}

Financial support via the NRF Rated Researchers' Incentive Funding is gratefully acknowledged.

\section{Competing interests}

The author declares that he has no financial or personal relationship(s) which may have inappropriately influenced him in writing this article.

\section{References}

Bassler, J.M., 2007, Navigating Paul: An introduction to key theological concepts, Westminster John Knox, Louisville, London.

Bourdieu, P., 1990, The logic of practice, University of Stanford Press, Stanford.

Campbell, D.A., 2005, The quest for Paul's Gospel: A suggested strategy, T\&T Clark International, New York, London.

Cranfield, C.E.B., 1982 [1975], A critical and exegetical commentary on the epistle to the Romans, vol. 1, T \& T Clark, Edinburgh. (International Critical Commentary).

Crossan, J.D. \& Reed, J.L., 2004, In search of Paul: How Jesus's apostle opposed Rome's empire with God's Kingdom: A new vision of Paul's words and world, Harper, San Francisco, New York.

52 . With the opposite true as well, the ambiguity remains throughout: 'Epic's losers, the enemies of empire whom epic ideology assimilates with the East, woman nature, irrationality, chaos, consequently also embody a potential, indeed inevitable, collapse of narrative' (Quint 1989:27). Furthermore, the romance narrative with its divergences and offering alternative plot lines even if incoherent at times stand in a subversive relationship to the epic plot line (Quint 1989:15).

53.Cf. also Ephesians 2:11-22 and Colossians 1 for claims that Jesus Christ is the cosmic peacemaker, establishing peace on an unprecedented scale and of a nature contrary to that of the Roman Empire. This also does not occur without ambiguity: On the one hand, the death of Jesus is the substitute for imperial-style, big-scale spilling of blood and repression, but on the other hand, the violence surrounding spilling of blood and repression, but on the other hand, the violence surrounding
Jesus' death frames the contexts and metaphors used to express another content but similar form, peace through violence. 
Dunn, J.D.G., 1988, Romans 1-8, Word Books, Dallas. (Word Biblical Commentary).

Dunn, J.D.G., 1999, 'Spirit speech: Reflections on Romans 8:12-27', in S.K. Soderlund \& N.T. Wright (eds.), Romans and the people of God: Essays in honor of Gordon $D$ Fee on the occasion of his 65th birthday, pp. 82-91, Eerdmans, Grand Rapids, Cambridge.

Elliott, N., 1994, Liberating Paul: The justice of God and the politics of the apostle, Orbis, Maryknoll. (The Bible \& Liberation, vol. 6).

Elliott, N., 2007, 'Political formation in the letter to the Romans', in R.L. Brawley (ed.), Character ethics and the New Testament: Moral dimensions of scripture, pp. 179-190, WJK, Louisville. PMid:17094019

Elliott, N., 2008, The arrogance of nations: Reading Romans in the shadow of empire, Fortress, Minneapolis. (Paul in Critical Contexts).

Faber, R., 2000, 'Vergil's 'Shield of Aeneas' (Aeneid8.617-731)and the Shield of Heracles', Mnemosyne 53(1), 49-57. http://dx.doi.org/10.1163/15685250052822027

Fitzmyer, J.A., 1993, Romans, Doubleday, New York. (Anchor Bible Commentary, vol. 33).

Fretheim, T.E., 2005, God and world in the Old Testament: A relational theology of creation, Abingdon, Nashville.

Gaventa, B.R., 2007, Our mother Saint Paul, WJK, Louisville, London.

Georgi, D., 1991, Theocracy in Paul's praxis and theology (Gott auf den Kopf Stellen), transl. D.E. Green, Fortress Press, Minneapolis.

Gowing, A.M., 2005, Empire and memory: The representation of the Roman republic in imperial culture, Cambridge University Press, Cambridge. (Roman Literature and Its Contexts). http://dx.doi.org/10.1017/CBO9780511610592, PMCid:1560004

Horsley, R.A. (ed.), 1997, Paul and empire: Religion and power in Roman imperial society, Trinity Press International, Harrisville. PMCid:1050919

Horsley, R.A. (ed.), 2000, Paul and politics: Ekklesia, Israel, imperium, interpretation Essays in honor of Krister Stendahl, Trinity Press International, Harrisville.

Horsley, R.A. (ed.), 2004, Paul and the Roman imperial order, Trinity Press International, Harrisville.

Howard-Brook, W., 2010, 'Come out my people!': God's call out of empire in the Bible and beyond, Orbis, Maryknoll.

Howell, D.N. Jr, 1994, 'The Center of Pauline Theology', Bibiotheca Sacra 151(601), 50-70.

Jewett, R., 2004, 'The corruption and redemption of creation: Reading Rom 8:18-23 within the imperial context', in R.A. Horsley (ed.), Paul and the Roman imperial order, pp. 25-46, Trinity Press International, Harrisville.

Kahl, B., 2010, Galatians re-imagined: Reading with the eyes of the vanquished, Fortress, Minneapolis. (Paul in Critical Contexts.)

Keesmaat, S.C., 1999, 'Paul and His Story: (Re)Interpreting the Exodus Tradition', Journal for the Study of the New Testament, suppl. ser. 181.

Levison, J.R., 1993, 'Creation and new creation', in G.F. Hawthorne, R.P. Martin \& D.G. Reid (eds.), Dictionary of Paul and his letters, pp. 189-190, InterVarsity Press, Leicester.
Longenecker, R.N., 2011, Introducing Romans: Critical issues in Paul's most famous letter, Eerdmans, Grand Rapids.

Lopez, D.C., 2008, Apostle to the conquered: Reimagining Paul's mission, Fortress, Minneapolis. (Paul in Critical Contexts).

Martin, D.B., 1995, The Corinthian body, Yale University Press, New Haven, London.

Mattingly, D.J., 2010, Imperialism, power, and identity: Experiencing the Roman empire, Princeton University Press, Princeton.

Meech, J.L., 2006, Paul in Israel's story: Self and community at the cross, Oxford University Press, Oxford, New York. (AAR Academy Series). http://dx.doi. org/10.1093/0195306945.001.0001

Michaels, J.R., 1999, 'The redemption of our body: The riddle of Romans 8:19-22', in S.K. Soderlund \& N.T. Wright (eds.), Romans and the people of God: Essays in honor of Gordon D Fee on the occasion of his 65th birthday, pp. 92-114, Eerdmans, Grand Rapids, Cambridge.

Moo, D., 1996, The epistle to the Romans, Eerdmans, Grand Rapids.

Perkins, J., 2009, Roman imperial identities in the early Christian era, Routledge, London. (Routledge Monographs in Classical Studies).

Punt, J., 2012, 'Empire and New Testament Texts: Theorising the Imperial, in Subversion and Attraction', HTS Teologiese Studies/Theological Studies 68(1), Art. \#1182, 11 pages. http://dx.doi.org/10.4102/hts.v68i1.1182

Quint, D., 1989, 'Epic and Empire', Comparative Literature 41(1), 1-32, viewed 09 March 2011, from http://www.jstor.org/stable/1770677

Segal, A.F., 2004, Life after death: A history of the afterlife in western religion, Doubleday, New York.

Sobrino, J., [1978] 2002, Christology at the crossroads: A Latin American approach, Wipf \& Stock, Eugene.

Stowers, S.K., 1994, A rereading of Romans: Justice, Jews and Gentiles, Yale University Press, New Haven, London.

Sutter Rehman, L., 2004, 'To turn the groaning into labor: Romans 8:22-23', in A. Levine \& M. Blickenstaff (eds.), A feminist companion to Paul, pp. 74-84, Feminist companion to the New Testament and Early Christian Writings, vol. 6, T\&T Clark, Continuum, London.

Revell, L., 2009, Roman imperialism and local identities, Cambridge University Press, Cambridge.

Ruether, R.R., 1996, 'Gender Equity and Christianity: Premodern Roots, Modern and Postmodern Perspectives, Union Seminary Quarterly Review 50(1-4), 47-61.

Vella, H.C.R., 2004, 'Vergil's Aeneid VIII and the Shield of Aeneas: Recurrent Topics and Cyclic Structures', Studia Humaniora Tartuensia 5(A.1), 1-17, viewed 24 February 2012, from http://www.ut.ee/klassik/sht/2004/vella1.df

Wallace, D.R., 2008, The Gospel of God: Romans as Paul's Aeneid, Wipf \& Stock, Eugene.

Westerholm, S., 1997, Preface to the study of Paul, Eerdmans, Grand Rapids. PMCid:1128947

White, J.L., 1999, The apostle of God: Paul and the promise of Abraham, Hendrickson, Peabody.

Yonge, C.D., 1993, The Works of Philo Judaeus, transl. C.D. Yonge, H.G. Bohn, London PMid:8132921 